\title{
Coincidence of Hürtle cell carcinoma and non invasive follicular neopasm with papillary-like nuclear features (NIFTP) of the thyroid: A Case Report
}

\author{
Authors \\ Kreze $A^{1^{*}}$, Koskubová $D^{1}$, Tresnerová $K^{1}$, Koutníková $\mathbf{H}^{2}$, Podlešák $T^{3}$, Špůrková $Z^{2}$ \\ ${ }^{1}$ Internal Department Hospital Bulovka, Prague, Czech republic \\ ${ }^{2}$ Department of Pathology Hospital Bulovka, Prague, Czech republic \\ ${ }^{3}$ Department of Otorhinolaryngology Hospital Bulovka, Prague, Czech republic
}

*Corresponding Author

Kreze A

Internal Department Hospital Bulovka, Prague, Czech republic

\section{Introduction}

Collision tumours are defined as geographically coexistent but histologically distinct and morphologically independent neoplasms (Brandwein-Gensler et al.). We report a combination of Hürtle cell carcinoma and NIFTP. Thus, we add this combination to the group of collision tumours in the thyroid.

\section{Case history}

69-year-old female presented with a growing mass on right side of neck.

Ultrasound thyroid gland was: right lobe $7.2 \mathrm{ml}$, left lobe $2.3 \mathrm{ml}$, hypoechogenic nodus 18x19x23 $\mathrm{mm}$ with microcalcifications and higher vascular flow in right lobe. Laboratory status: euthyrosis (TSH $1.31 \mathrm{mU} / \mathrm{l}$. FT4 $15.9 \mathrm{pmol} / \mathrm{l}$ ). Fine needle aspiration cytology of nodus showed the result: Bethesda III (oncocytic lesion of uncertain malignant potential). We recommend right-sided lobectomy with perioperative histology. Rightsided lebectomy was done.
Definitive histological finding was Hürtle cell carcinoma and NIFTP (Fig.1-4). It was completed by left-side lobectomy and subsequently applied therapeutic $\mathrm{NaJ}^{*}$.

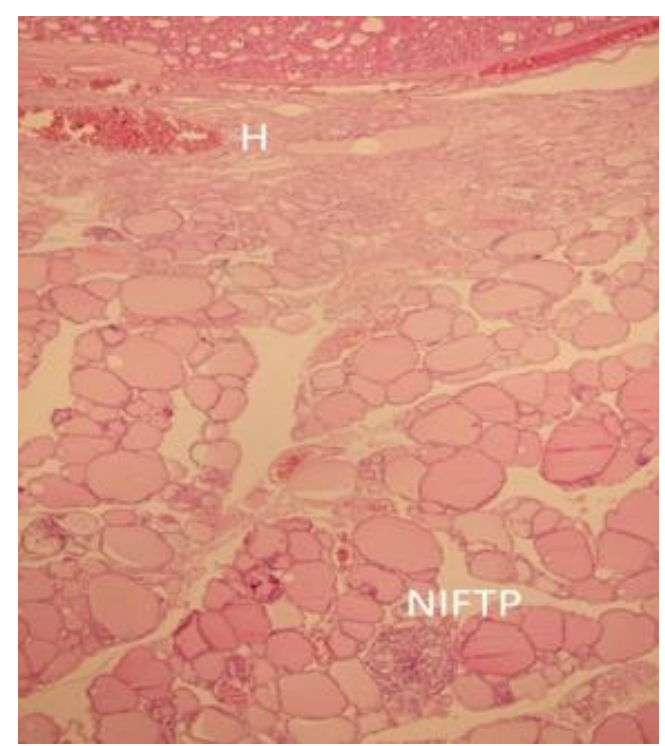

Fig 1- Hürthle cell carcinoma and NIFTP in thyroid 


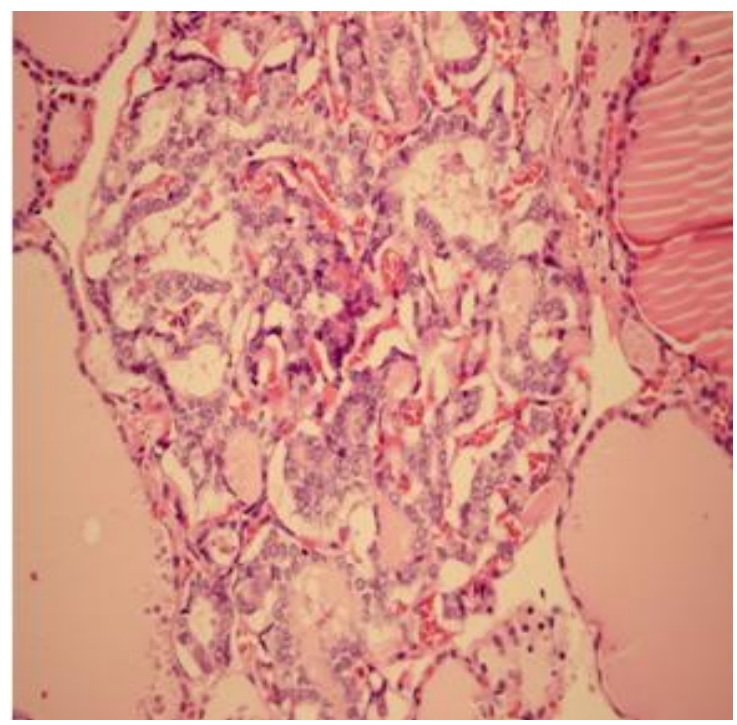

Fig 2- Detail of NIFPT

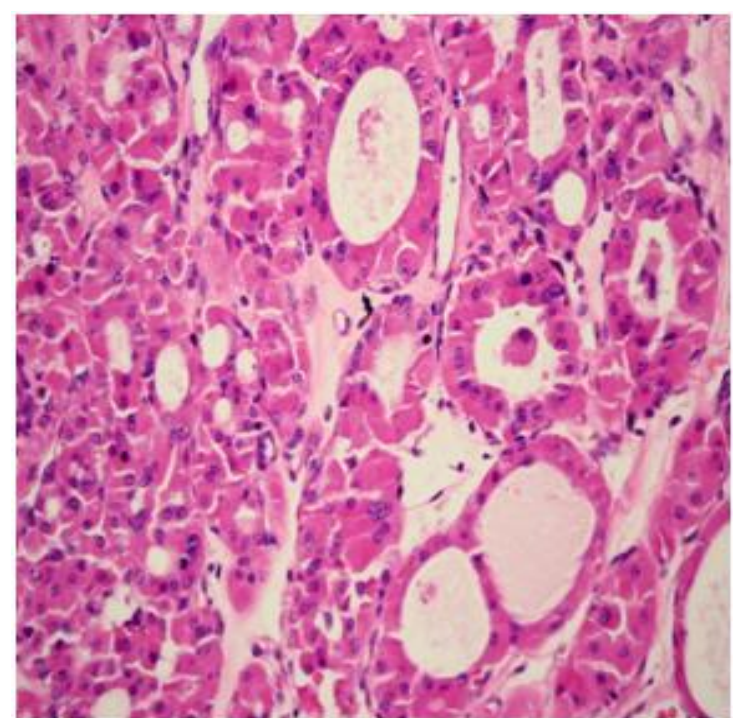

Fig 3- Detail of Hürthle cell carcinoma

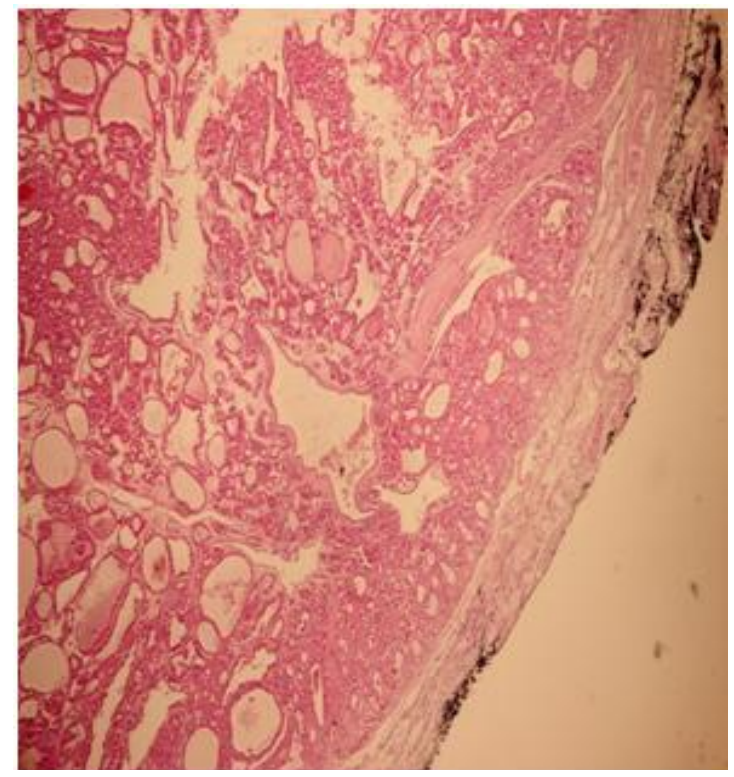

Fig 4- Hürthle cell carcinoma-area of capsular invasion

\section{Discussion}

Bilroth established the first criteria for multiple primary tumours in 1879 , simplified by Warren to 3 conditions: each tumour demonstrates a definitive picture of malignancy, each tumour must be distinct and the possibility that one was a metastasis must be excluded (Warren et al.).

There are reports of the coexistence of Hürtle cell carcinoma and the tall cell variant of papillary carcinoma in the same thyroid lobe (Baloch et al.), Hürtle cell carcinoma and follicular carcinoma (Khethmal et al.), and Hürtle cell adenoma with papillary microcarcinoma (Rana et al.).

There is a limited body of information on how these tumours could be managed. Surgical management with appropriate adjunct therapy is recommended. The presence of two primary cancers should be considered as signifying an aggressive potential and also an increased risk of recurrence (Thomas et al.).

In summary, we report a collision tumour compromised of Hürtle cell carcinoma and NIFTP, which has not been reported so far.

\section{References}

1. Brandwein-Gensler M, Urken M,Wang B (2004) Collision tumor of thyroid: a case report of metastatic liposarcoma plus papillary thyroid carcinoma. Head Neck 26: 637-641

2. Warren S, Gates G (1932) Multiple primary malignant tumors. Am J Cancer 16:1358-1414

3. Baloch ZW, Mandel S, LiVolsi VA (2001) Combined tall cell carcinoma and Hürtle cell carcinoma (collision tumor) of the thyroid. Arch Pathol Lab Med 125(4):541543

4. Khethmal P, Kumar A (2018) Collision Tumor of Thyroid: A Rare Case Report. JSM Clin Case Rep 6(10): 1079-1080

5. Rana C, Kumari N (2018) Hürtle Cell Adenoma and Papillary Microcarcinoma in Thyroid: Collision Tumors. Word J Endocr Surg 10(2):134136 
6. Thomas VP, George R (2018) Collision tumors of the thyroid: Review of literature and report of a case of papillary-follicular collision tumor. Thyroid Res Pract 15:60-4. 